Journal of Applied Business, Taxation and Economics Research (JABTER)

Vol. 1, No. 2, 2021 (Page: 193-204)

DOI: $10.54408 /$ jabter.v1i2.18

E-ISSN 2808-263X

\title{
Islamic Law Overview on Implementation of Murabahah Bil Wakalah on Multi-Purpose Financing Products
}

\author{
Mualim $^{1}$, Hendra Karunia Agustine ${ }^{2}$, Annisa Hariyani ${ }^{3^{*}}$ \\ Husnul Khotimah Islamic College $e^{1,2,3^{*}}$ \\ Corresponding Author: hariyaniannisa@gmail.com ${ }^{3 *}$
}

Keywords : Islamic Law Review,

Murabahah bil Wakalah, Multipurpose

Financing Products

\begin{abstract}
:
This study aims to examine the implementation of Murabahah bil Wakalah on multipurpose financing products in a review of Islamic Law. The research method used in this research is field research (field research). The types and sources of data in this study used primary and secondary data. Data collection techniques through interviews, observation, and documentation. The data obtained in this study are conclusions from various processes in qualitative research. Starting from data collection, selecting appropriate data, presenting data and then concluding.

The results of this study are murabahah bil wakalah contracts in multipurpose financing at BPRS HIK Parahyangan, murabahah contracts are carried out simultaneously with wakalah contracts. Where the murabahah contract is carried out at the beginning to determine the selling price, the agreed profit, and the installment period.
\end{abstract}




\section{Introduction}

BPRS (Islamic People's Credit Bank) is one of the Islamic financial institutions in addition to sharia commercial banks that is growing rapidly and is popular in various regions in Indonesia. Operationally, BPRS has similarities with Islamic commercial banks, BPRS does not provide services in payment traffic. But these two institutions offer sharia transactions covering various savings and financing products. (Wirdyaningsih, 2005)

As an institution that can collect and distribute public funds effectively and efficiently (financial intermediary), Islamic banks have a main activity in the form of collecting funds from the public through deposits in the form of demand deposits, savings, and deposits that use the wadi'ah yad al-dhamanat principle ( deposit), and mudharabah (profit sharing investment). Then redistribute these funds to the general public in various forms of financing schemes, such as buying and selling or al-ba'i schemes (murabahah, salam, and istishna), rental (ijarah), and profit sharing (musyarakah and mudharabah), as well as complementary products. , namely fee-based services, such as hiwalah (transfer of accounts payable), rahn (pawn), qardh (debts receivable), wakalah (representative, agent), kafalah (bank guarantee). (Lathif, 2012:69)

The developments experienced by humans today have an impact on financial institutions, where they are required to create financial products that modern society needs. Islamic finance/business products are experiencing developments that adapt to the contemporary economic needs of the global community. With very complex needs, financial transactions must implement new contracts that are adapted to current needs, taking into account the validity of the contracts that build them. (Susamto, 2016:202)

Newly formed contracts are generally the result of a combination of pre-existing contracts which are then formed in such a way as to become a harmonious contract. The result of this combination of contracts is known as a hybrid contract or multi contract (al-uqud almurakhabah). Multi contract is an agreement of two parties to carry out a transaction that includes two or more contracts, so that all legal consequences of the combined contract and all rights and obligations arising from it are considered as an inseparable unit. (Aryanti, 2017:178)

A preliminary study with Mr. Ade Basar conducted while at BPRS HIK Parahyangan Kuningan branch, he explained that BPRS HIK Parahyangan is a sharia financial institution that is engaged in providing savings and loan services for its customers who offer products in the form of savings and deposits, while in disbursement of funds offers consumer financing products and productive financing as well as working capital with the principles of murabahah, mudharabah and musyarakah contracts.

In the products it produces, BPRS Harta Insan Karimah uses different contracts according to the needs of each transaction. To meet the needs of transactions with customers, it is not uncommon for Islamic banks to apply the concept of multiple contracts or multiple contracts in one transaction contract. In one product, there is not only one contract, but also two to three 
accompanying contracts. This is done by the BPRS to meet contractual needs in financing with customers that cannot be fulfilled by using only 1 (one) contract.

Multipurpose financing is a product that applies the principle of multi-contract. The contract used in multipurpose financing itself is the murabahah contract as the main contract and the wakalah contract as the accompanying contract. Multipurpose financing is a financing product that can help meet people's needs when financial conditions are difficult and in order to respond to customer needs, which are increasingly varied. other consumers. Because the emergence of new products in Islamic financial institutions has resulted in difficulties in implementing sharia principles, especially in the aspect of conformity with contracts (akad). To answer this question, through the fatwa of the National Sharia Council (DSN) has tried to provide answers to the needs of products that have just been known to apply sharia law. (Maksum Muhammad, 2014:50)

The ideal murabahah bil wakalah is one based on the murabahah provisions in the National Sharia Council Fatwa Number 04/DSN-MUI/IV/2000. Murabaha is selling an item by confirming the purchase price to the buyer and the buyer pays it at a higher price as profit. It can be illustrated in this case that Islamic banks finance part or all of the purchase price of goods or commodities whose qualifications have been agreed upon, Islamic banks are the ones who buy goods or commodities that have been agreed upon, purchases must be legal and free of usury. Then, the bank must convey all matters relating to the purchase of goods or commodities. After the bank owns the goods/commodities, the bank then sells the goods/commodities to customers (customers) at a selling price equal to the purchase price plus profit. The customer concerned pays the agreed price of the goods/commodity within a certain agreed period of time. If a sharia bank wants to represent its customers to buy goods/commodities from a third party, the Murabahah sale and purchase contract must be made after the goods in principle become the property of the sharia bank concerned. (Fatwa of the National Sharia Council of the Indonesian Ulema Council Number 04/DSN-MUI/IV/2000, 2000:3-4).

Conceptually, the DSN Fatwa regulation No. 04/DSN-MUI/IV/2000 states that the condition for milkiyah (ownership of goods) occurs in the form of a murabaah bil wakalah contract, in which the bank represents the customer to buy the goods he needs. In practice, first, banks complete the murabaah contract first to the customer. During the contract process, there is no handover of goods between the bank and the customer, then the bank also does not have the goods in principle. Second, when the murabaah contract is completed, the bank only hands over a certain amount of money to the customer to buy the goods they need. In this second process, the wakalah contract applies. In the practice above, it shows that banks do not have these goods in principle. Though the terms of ownership is an absolute thing in buying and selling. If this contract is continued, it becomes another way to usury, because in principle there is no buying and selling process, what happens is that the bank only lends a certain amount of money and then the 
customer pays it in installments with added margin. This means that banks carry out practices such as interest in conventional banking. (Sulaiman, 2014:56-57)

Even in practice in the field, customers are given financing regardless of the object to be traded. So that the impression appears for customers who are accustomed to consumptive credit schemes that "Islamic banks are the same as conventional banks", because customer needs are no longer for purchasing goods but for fresh funds. Some even argue that murabahah is not buying and selling but hilah with the aim of taking usury (Afrida, 2016:163). In fact, the sale and purchase of murabahah is not a loan that is given with interest, but is a sale and purchase of commodities at a tough price including a profit margin above the mutually agreed acquisition cost. (Maruta, 2016:91). Therefore, it is necessary to explain and ensure that the implementation of the murabahah system in Islamic banks is in accordance with sharia provisions and its application to the implementation of murabahah contracts. So that makes the author interested in conducting research on the purity of the system and the implementation of murabahah financing contracts implemented by Islamic banking institutions when viewed from the perspective of fiqh and applicable regulations. For this reason, the researcher chose one of the Islamic banks that uses a murabahah contract, namely BPRS Harta Insan Karimah Parahyangan.

\section{Research Method}

Research methods

The research method used in this research is Field Research, which is a study that aims to collect data from the research location or field (Fatmawati Anwar, 2018; 10). Intended to learn more in depth about the multipurpose financing mechanism contained in PT. BPRS Harta Insan Karimah Parahyangan Kuningan branch.

\section{Data Types and Sources}

This research is a qualitative research. With a qualitative approach, the author conducts an analysis by outlining, explaining, and describing in detail through the results of interviews and documents conducted at BPRS HIK Parahyangan Kuningan. In this study, the researchers tried to reveal how the implementation of the multipurpose financing mechanism at BPRS HIK Parahyangan Kuningan branch. While the data sources are obtained from primary and secondary data sources.

\section{Data Collection and Analysis Techniques}

In this study, the authors use several methods to obtain data, the methods used include observation, interviews, and documentation. The data obtained in this study were analyzed using three methods, namely data reduction, data display (data presentation), and drawing conclusions. 


\section{Result and Discussion}

In terms of the use of contracts in multipurpose financing, BPRS HIK Parahyangan uses murabahah and wakalah contracts, which means having more than one (multi) contract or what is commonly called multi-agreement. Murabahah bil Wakalah is the implementation of the multicontract application that has been developed by Islamic banking.

The validity of the contract (syuruth ash-shihah), the contract will have legal consequences. A contract is considered valid by syara' if there is a balance with the pillars and conditions set by syara' law. Precisely if the main contract in multipurpose financing uses a murabahah contract, then all forms of Islamic bank operations must be in accordance with the murabahah fatwa, because the legal consequences provided by the murabahah contract, the customer pays for the goods sold by the bank plus the agreed profit. (Saroh, 2017:78)

According to Yenti Afrida, this murabahah financing uses a sale and purchase agreement, so in this murabahah financing there must be pillars and conditions of sale and purchase. The pillars of buying and selling murabahah agreed upon by Jumhur Ulama are: Ba'i or seller; Musytari or buyer; Mabi' or goods are commodities, objects, objects that are traded; Tsaman or selling price, is as a measuring tool to determine the value of an item; ljab and Qabul as outlined in the contract. (Afrida, 2016:159-160)

Meanwhile, the provisions of the pillars of murabahah in the Fatwa of the National Sharia Council of the Indonesian Ulema Council No.04/DSNMUI/IV/2000 are: "there are parties who make the contract, namely the seller and the buyer; the object of the contract, which includes the goods being traded and the price; contract/Sighat consisting of ljab (deliver) and Qabul (receive)." (Fatwa of the National Sharia Council of the Indonesian Ulema Council Number 04/DSN-MUI/IV/2000, 2000)

The results of the interview with Mr. Ade Basar stated that, in the murabahah agreement or contract for multipurpose financing at BPRS HIK Parahyangan Kuningan, the parties making the contract are the Bank as Ba'i or seller, customer as musytari or buyer, goods/needs as Mabi' or object. which is traded, Tsaman as the selling price, and ljab and qabul which are stated in a written agreement in the form of a draft contract, which contains articles that explain all rights and obligations that must be fulfilled by the Bank and by the customer. Which in the end was signed by the parties, namely the bank and the customer in one assembly, namely at the BPRS HIK Parahyangan Kuningan office. (Ade Basar, Interview, September 6, 2021)

It's just that in practice the murabahah mechanism carried out by BPRS HIK Parahyangan is not fully in accordance with the regulations set by the DSN-MUI Fatwa. Based on these interviews, researchers can analyze the mechanism of murabahah in the practice of multipurpose financing, it can be seen that several pillars have not been fulfilled, first, namely Ba'i is the seller / party who owns the goods. In this case, the position of BPRS HIK Parahyangan is not as a pure seller who does have inventory of goods or commodities before making murabahah with 
customers. In practice the bank will only represent the customer to buy the item with funds issued by the bank,

Second, namely Mabi' or goods to be traded, in the statement of the DSN-MUI fatwa the terms of Mabi' goods must officially become the property of the seller and the substance and contract are halal. In this case, the position of BPRS HIK Parahyangan does not meet these requirements, namely the goods are not yet owned by the bank, and the bank does not have a role in the purchase, the bank only provides funds in the form of realized financing. This, of course, injures the pillars of buying and selling, because the goods being traded must officially become the property of the bank. The bank makes a murabahah contract with goods that are not legally owned by the bank. However, the selling price and profit margin have been agreed upon by the bank.

Third, namely the selling price of goods/needs, in this case the bank must notify the customer of the cost of capital as a valid condition for murabahah. In this case the position of BPRS HIK Parahyangan does not meet these requirements, namely the price which is the main benchmark for the bank to determine the margin, not from the ownership of the goods. But from the submission of the amount of financing that the customer proposes. The bank does not yet have the goods needed by the customer, so the bank authorizes the customer to purchase the goods/needs needed through a wakalah contract.

Next, analyze the use of two contracts, namely murabahah and wakalah in multipurpose financing of BPRS HIK Parahyangan. Murabahah bil wakalah is a sale and purchase with wakalah as an accompanying contract. In this sale and purchase, the financial institution represents the purchase of goods to the customer, in which the customer takes the side as an agent of the financial institution. Thus, the first contract is the wakalah contract, after the end of the wakalah contract, it is marked by the delivery of goods to the Islamic financial institution. The second contract is Murabahah, where the bank delivers the ordered goods that have been purchased by the customer, then the institution determines the margin obtained and the payback period that will be agreed upon by the Islamic financial institution and the customer. at this time the sale and purchase of Murabahah occurs with the signing of the Murabahah contract after the wakalah contract is completed.

The act of a murabahah contract with wakalah raises the potential for usury and gharar. In order for this murabahah contract with wakalah not to cause usury and gharar, it is arranged according to the applicable provisions. According to the National Sharia Council Fatwa No. 04/DSN-MUI/IV/2000 the first provision point 9 that "If the bank wants to represent the customer to buy goods from a third party, the murabahah sale and purchase contract must be carried out after the goods, in principle become the property of the bank". The meaning of this provision is that if the bank represents the customer to buy goods from a third party, then the sale and purchase contract must be made after the goods in principle become the property of the bank. 
Therefore, the wakalah contract occurs first before the murabahah contract because the wakalah contract will end when the customer submits the goods that have been purchased to the bank,

Whereas in the practice of murabahah bil wakalah contracts on multipurpose financing at BPRS HIK Parahyangan, murabahah contracts are carried out simultaneously with wakalah contracts. Where the murabahah contract is carried out at the beginning to determine the selling price, the agreed profit, and the installment period. after that on the same day the bank and the customer immediately entered into a wakalah contract, namely the bank gave power to the customer to purchase goods. Then the bank disburses the funds to the customer's account. This certainly violates the provisions in the DSN-MUI fatwa.

From the results of the interview with Mr. Ade Basar, the basic reason why the murabahah contract precedes the wakalah contract, is because if the murabahah contract is not carried out first, it is feared that the customer will default, such as the customer not wanting to buy goods or the customer bringing the goods without paying the payment, causing the bank to bear the risk of loss. Because the bank does not provide a binding agreement facility to the customer so that the customer buys the desired item, the agreement is carried out directly by signing a murabahah contract. So that if a murabahah contract has been carried out, the customer will not be able to break the promise, because it is already

The Account Officer, Mr. Ade Basar and the staff of the Legal Officer, Mr. Arif, stated that there is uncertainty about the sharia of murabahah contracts, because at first glance it looks the same as financing at other commercial banks and they understand that in a murabahah contract, the goods must be provided by the bank, or the bank who should have bought the item. However, the practice in the field shows that customers who come to BPRS still have a conventional bank mindset where customers who come to Islamic BPRs can borrow funds for various purposes such as conventional banks.

From the explanation above, it can be seen that there are several practices that are not fully in accordance with the DSN-MUI Fatwa regulation. Among them are: first, the bank as a seller/provider of goods is not a pure seller who has inventory of goods or commodities because the bank does not own the goods. Second, the goods are still owned by the original seller so that when a murabahah transaction occurs, the goods do not yet exist. Third, the selling price that is notified to the customer is not the price of the goods that already belong to the bank, but from the amount of financing that the customer proposes. Fourth, the murabahah contract is carried out simultaneously with the wakalah contract. Whereas the purpose of this wakalah contract is to give power to the customer as a representative of the bank to buy goods/commodities traded in the murabahah contract.

From the results of interviews obtained by the author with Mr. Ade Basar and Mr. Arif, it is concluded that sharia education is still not balanced between Islamic financial institutions and the community. Islamic financial institutions have tried to apply sharia principles, but people still have a conventional bank mindset. 


\section{Conclusion}

Based on the results of the research that the researcher has done, it can be concluded that the implementation of multipurpose financing at BPRS HIK Parahyangan Kuningan uses two contracts, namely, the murabahah bil wakalah contract. Murabahah contract/agreement with the customer is to agree on the selling price, agreed profit, and installment period. If the customer agrees then the next is the wakalah (representative) contract. After one month from the disbursement of funds, the bank will monitor the allocation of funds provided, in accordance with the initial financing by asking for a transaction note as real evidence.

According to Islamic law, there are several inconsistencies between the bank as a seller/provider of goods, not as a pure seller who has inventory of goods or commodities because the bank does not own the goods. Second, the goods are still owned by the original seller so that when a murabahah transaction occurs, the goods do not yet exist. Third, the selling price that is notified to the customer is not the price of the goods that already belong to the bank, but from the amount of financing that the customer proposes.

For the suitability of murabahah contracts in multipurpose financing products that occur at BPRS HIK Parahyangan Kuningan with DSN MUI Fatwa No.04/DSNMUI/IV/2000 there are several inconsistencies including: carried out simultaneously on the same day as the wakalah contract. By means of the bank disbursing funds to the customer's account, then the bank and the customer perform a wakalah contract, namely the bank gives power to the customer to purchase goods. Second, on the provisions of murabahah to customers in the second provision point 2 that the discrepancy is when the murabahah contract is made.

\section{References}

Afrida, Y. (2016). Analysis of Murabahah Financing in Islamic Banking. JEBI (Journal of Islamic Economics and Business), 1(2).

Akmal, H., \& Sirajulhuda, MH (2019). Fiqh Muamalah Review of Multi Contract Transactions in the DSN-MUI Fatwa on Sharia Short-Term Liquidity Financing. Al-Istinbath: Journal of Islamic Law, 4(2), 195-212. https://doi.org/10.29240/jhi.v4i1.922

Action, H. (2018). Murabahah Credit in the Hadith Book of Al-Tis'ah (Analysis of Buying and Selling Installments / Required in Sharia Law). Sharia: Journal of Law and Thought, 18(2).

Al-Hakim, S. (2013). The development of sharia banking regulations in Indonesia. ljtihad, Journal of Islamic Law and Humanitarian Discourse, 13(1).

Alfin, A. (2015). Multi Akad in Fiqh Perspective and its Implementation in Islamic Banking. AlHurriyah, 16(1).

Antonio, MS (2001). Islamic Banks: From Theory to Practice. Echo Insani Press. 
Aryanti, Y. (2017). Multi Contracts (Al-Uqud Al-Murakkabah) in Islamic Banking from the Fiqh Muamalah Perspective. JURIS (Journal of Shari'ah Scientific), 15(2), 177. https://doi.org/10.31958/juris.v15i2.498

Ascarya. (2006). Islamic Bank Contracts and Products: Concepts and Practices in Several Countries. Bank Indonesia.

Ascarya, \& Yumanita, D. (2005). Islamic Banks: Overview. Center for Education and Central Banking Studies (PPSK) BI.

Astuti, A. (2017). Implementation of the Murabahah bil Wakalah Agreement on the Financing Product of the KSPPS Binama Semarang. Walisongo State Islamic University, Semarang.

Az-zuhaili, W. (2011). Islamic jurisprudence wa fairatuhu. Human Echo.

Bahjatulloh, QM (2011). The Study of Murabaha Financing Between Theory and Practice. Sharia Economist, 2(2).

Dariana, \& Ismanto, W. (2020). Multiservice Financing Analysis with ljarah Contract (Study at PT BPRS Berkah Dana Fadhlillah Air Tiris, Kampar Regency). JPS (Journal of Islamic Banking), vol.1(No.1).

Ministry of Religion RI. (2007). Al-Qur'an and its Translation. Shamil Qur'an.

EM, MAG (2001a). Tafsir Ibn Kathir Volume 2. Library of Imam ash-Shafi'i.

EM, MAG (2001b). Tafsir Ibn Kathir Volume 3. Library of Imam ash-Shafi'i.

Fatimah, L. (2018). Implementation of Wakalah in Murabahah Financing at BMT Artha Berkah Ansoruna Mataram Baru, East Lampung. State Islamic Institute (IAIN) Metro.

Fatmawati Anwar, N. (2018). ISLAMIC LAW ANALYSIS OF HYBRID CONTRACT IN MULTI-SERVICE IJARAH FINANCING PRODUCTS IN SHARIA BANKING (Study at PT BPRS Bandar Lampung). STATE ISLAMIC UNIVERSITY OF RADEN INTAN LAMPUNG.

fatwa of the National Sharia Council (DSN) No. 04/DSN-MUI/IV/2000.

Harahap, DC (2020). IMPLEMENTATION ANALYSIS OF MURABAHAH BIL WAKALAH CONTRACT ON IMPLANT BSM FINANCING PRODUCTS (Case Study of Bank Syariah Mandiri Binjai Branch). North Sumatra State Islamic University.

Hardhani, Andriani, H., Ustiawati, J., \& Utami, EF (2020). Qualitative and Quantitative Research Methods. CV Science Library.

Hasanuddin. (2009). MULTI AKAD IN CONTEMPORARY SHARIA TRANSACTIONS IN SHARIA FINANCIAL INSTITUTIONS IN INDONESIA: Concepts and Provisions (Dhawabith) in Fiqh Perspective. 1-24. 
Ilyas, R. (2015). The Concept of Financing in Sharia Banking. 9(1), 183-204.

Khoeriyah, E. Al. (2020). Implementation of the Murabahah Bil Wakalah Agreement on BRISyariah iB KPR Financing. (Case Study of BRISyariah KC Bandar Lampung Kedaton). METRO STATE ISLAMIC RELIGION INSTITUTE (IAIN).

Lathif, AA (2012). Concept and Application of Murabahah Contract in Islamic Banking in Indonesia. Ahkam, XII(2).

Lestari, T. (nd). A Review of Sharia Economic Law on the Practice of Murabahah Bil Wakalah at BNI Syariah Panorama Bengkulu Branch. Bengkulu State Islamic Institute (IAIN).

Maksum Muhammad. (2014). Contract Models in Islamic Financial Products. Al-Adalah, XII (Jalan Ir. H. Juanda No. 95 Ciputat Timur, Tangerang, Banten), 50. file://C:/Users/ASUS/Downloads/174-787-1-PB.pdf

Malik, Abdul. (2020). OJK: Assets \& Market Share of Sharia Banking Increases During the Pandemic, Here's the Data. https://www.bareksa.com/berita/pasar-modal/2020-0923/ojk-aset-market-share-perbankan-syariah-meningkat-di-masa-pandemi-ini-data

Maruta, H. (2016). MUDHARABAH, MUSYARAKAH, AND MURABAHAH CONTRACTS AND THEIR APPLICATIONS IN COMMUNITY. IQTISHADUNA: Our Scientific Journal of Economics.

Masykrin, U. (2012). Murabbahah: Between Theory and Practice at PT. Bank Syariah Mandiri Malang City. Maulana Malik Ibrahim State Islamic University, Malang.

Maulana, H. (2016). Multiakad in Contemporary Sharia Transactions at Islamic Financial Institutions in Indonesia. Al-lqtishad: Journal of Islamic Economics, 3(1). https://doi.org/10.15408/aiq.v3i1.2518

Muhammad. (2008). Sharia Economics. Graha IImu.

Fatwa of the National Sharia Council of the Indonesian Ulema Council Number 04/DSNMUI/IV/2000, (2000).

National Sharia Council Fatwa No. 10/DSN-MUI/IV/2000, (2000).

Muslich, AW (2013). Fiqh Muamalat (2013th ed.). AMZAH.

Najamuddin, H. (2013). Al-'Uqûd Al-Murakkabah in Sharia Economic Perspective. Shari'ah Journal, II.

Nasila, R., \& Zainuddin, Y. (2020). Analysis of Multipurpose Muamalat IB Financing on Murabahah Scheme at Bank Muamalat Gorontalo Branch. Madani: Scientific Service Journal, 3(2).

Nasution, J. (2015). UNDERSTANDING THE UNSHARIA OF SHARIA BANK. AL-MASHARIF, 3(2). http://repo.iain-padangsidimpuan.ac.id/310/1/115-328-1-PB.pdf 
Nasution, MLI (2018). Islamic Bank Financing Management. FEBI UIN-SU Press.

Nugrahani, F. (2014). Qualitative research methods in Language Education Research.

Nurhikma. (2019). Hybrid contract implementation on murabahah bil wakalah financing at BNI Syariah Makassar branch. PAREPARE STATE ISLAMIC RELIGION INSTITUTE.

Nursapiah. (2020). Qualitative Research. Wal Ashri Publishing.

Financial Fervices Authority. (nd). Sharia Banking Statistics. https://www.ojk.go.id/id/kanal/syariah/data-dan-statistik/statistik-perbankansyariah/Pages/Statistik-Perbankan-Syariah---April-2021.aspx

Purnamasari, ID (2011). Complete Guide to Popular Practical Law Smart, Easy, and Wise Tips for Understanding Sharia Contract Issues. Kaifa.

Editor, T. (2008). Big Indonesian Dictionary (KBBI). LANGUAGE CENTER OF THE NATIONAL EDUCATION DEPARTMENT.

Rivai, V., \& Veithzal, AP (2008). Islamic Financial Management. Press Eagle.

Roifah, A. (2015). Implementation of Murabahah bil Wakalah Financing as an Effort to Improve the Economy of Cattle Breeders at LKS ASRI Sendang Branch. Tulungagung State Islamic Institute (IAIN).

Saroh, LWM (2017). Implementation of Multi Contracts in Multi-Service Financing Products at the Syariah People's Financing Bank Mitra Harmoni Malang Overview of the Indonesian Ulema Council Malang City. Maulana Malik Ibrahim State Islamic University, Malang.

Siyoto, S., \& Ali Sodik, M. (2015). BASIC RESEARCH METHODOLOGY. Media Literacy Publishing.

Sudiarti, S. (2018). CONTEMPORARY MUAMALAH Fiqh. FEBI UIN-SU Press.

Sugiyono. (2013). Qualitative Quantitative Research Methods and R\&D. Alphabet.

Solomon, Sofia. (2014). MURĀBAAH CONTRADICATION DRAFT IN SHARIA BANKING AND SOME ISSUES REGARDING MURĀBAAH. Madania Journal, 4(1).

Supriyadi, A. (2003). Financing System based on Sharia Principles (A Juridical Review of Financing Practices in Islamic Banking in Indonesia). Al-Mawarid, $\mathrm{X}$.

Suryana. (2010). Research Methodology: A Practical Model of Quantitative and Qualitative Research. Indonesian education university.

Susamto, B. (2016). The Level of Use of Multi Contracts in the Fatwa of the National Sharia Council-Indonesian Ulema Council (Dsn-Mui). Al-Ihkam: Journal of Law \& Social Institutions, 11(1), 201. https://doi.org/10.19105/al-ihkam.v11i1.862 
Sya'diyah. (2019). Implementation of the Murabahah bil Wakalah contract at BRI Syariah KCP Plered from the perspective of the Fatwa of the National Sharia Council of the Indonesian Ulema Council. Sheikh Nurjati State Islamic Institute (IAIN) Cirebon.

Syafe'i, R. (2018). MULTI AKAD TRANSACTIONS IN FIKH PERSPECTIVE.

RI Law Number 10 of 1998 concerning Banking, (1998).

Wirdyaningsih. (2005). Sharia Islamic Banking and Insurance. date.

Wulan, R. (2018). Implementation of Wakalah contract in Murabahah financing at the Pekanbaru branch of BRI Syariah bank. Sultan Syarif Kasim State Islamic University, Riau-Pekanbaru.

Yayuk. (2018). MUAMALAH FIQH REVIEW ON HYBRID CONTRACT IN SHARIA BANKING. STATE ISLAMIC RELIGION INSTITUTE (IAIN) PONOROGO.

Yogaswara, R. (2009). Concept of Wakalah Contract in Fiqh Muamalah. https://viewislam.wordpress.com/2009/04/16/concept-akad-wakalah-dalam-fighmuamalah/

Yunus, M. (2019). HYBRID CONTRACT (MULTI AKAD) AND ITS IMPLEMENTATION IN SHARIA BANKING. TAHKIM, Journal of Civilization and Islamic Law, 2(1), 87-102. 